Gábor Pusztai

\title{
De moderne Hongaarse literatuur in Nederland
}

\author{
Interview met Mari Alföldy
}

Jij bent tegenwoordig de meest productieve vertaler van Hongaarse literatuur in Nederland. Hoe ben je vertaler geworden? Hoe ben je in Nederland terechtgekomen? Kun je iets over jezelf vertellen?

Ik heb tot mijn veertiende in Hongarije gewoond. Door het tweede huwelijk van mijn moeder gingen we toen in Nederland wonen. Daar maakte ik het gymnasium af en ging daarna klassieke talen studeren in Groningen. Een van de redenen waarom ik voor deze studiestad had gekozen was de aanwezigheid van de enige universitaire afdeling Hongaars in Nederland (en het hele Nederlandse taalgebied). Ik wilde namelijk graag inhalen wat ik op de middelbare school aan Hongaarse algemene ontwikkeling had gemist. Ik volgde vanaf mijn eerste jaar hogerejaars vertaalcolleges en vond het heel interessant om op die manier verbindingen aan te brengen tussen de twee talen die eigenlijk twee systemen waren in mijn hoofd, het Hongaars en het Nederlands. Later schreef ik me ook officieel in voor die studie als tweede hoofdvak.

In 1987 namen alle docenten en studenten deel aan de samenstelling van een Hongaars nummer van het later ter ziele gegane tijdschrift Bzzlletin. Daar heb ik twee teksten voor vertaald, een fragment van Péter Esterházy's nooit in het Nederlands vertaalde Productieroman en een fragment van de School aan de grens van Géza Ottlik. De docenten waren vooral erg kritisch en weinig stimulerend, mede daardoor heb ik me 
daarna meer dan tien jaar niet met vertalen beziggehouden. Pas halverwege de jaren negentig, na een paar jaar in het onderwijs, begon ik als freelance vertaler te werken, in de eerste plaats voor vertaalbureaus. Toen ik na enkele jaren de kans kreeg om mee te werken aan een Hongaars nummer van De Tweede Ronde, tijdschrift voor vertaalde literatuur, en daar positieve reacties op mijn vertalingen kreeg, schreef ik een uitgeverij aan, hetgeen tot mijn eerste literaire boekvertaling leidde: Nalatenschap van György Konrád. Vervolgens had ik het geluk dat de Wereldbibliotheek dringend iemand zocht voor de in Italië en Duitsland herontdekte roman Gloed van Sándor Márai, die vervolgens ook in Nederland in voor Hongaarse literatuur nooit vertoonde aantallen over de toonbank ging. Daarmee was mijn naam, voor zover een literair vertaler die heeft, enigszins gevestigd.

Wat is de positie van de Hongaarse literatuur in Nederland? Hoe zie jij dat?

Een paar jaar geleden zou ik geantwoord hebben dat de Hongaarse literatuur een bijzondere plaats inneemt in het literaire landschap van Nederland.

Vanaf het begin van de jaren '90 was György Konrád enorm populair onder Nederlandse intellectuelen, mede door de televisie-interviews die Wim Kayzer met hem maakte. Hij werd vertaald door Henry Kammer en later door een aantal anderen waaronder ondergetekende. In 2000 verscheen Gloed van Sándor Márai in het Nederlands, een boek dat oorspronkelijk in 1942 was verschenen en in de jaren '90 enorme oplages haalde in Italië en Duitsland, waarna het ook in het Nederlandse taalgebied enthousiast werd ontvangen. Vervolgens kreeg Imre Kertész, die in Nederland misschien wel bekender was dan in Hongarije, de Nobelprijs voor de literatuur, die hem uiteraard weer nieuwe lezers bezorgde. Aangemoedigd door het succes van Márai kregen uitgevers in dezelfde tijd ineens belangstelling voor klassieke Hongaarse auteurs, waardoor er boeken konden verschijnen van Dezső Kosztolányi, Antal Szerb en zelfs Géza Ottlik, al hoort die literair gezien niet helemaal in dat rijtje thuis. Vanaf 2013 zijn drie romans verschenen van László Krasznahorkai, die door critici zeer enthousiast werden begroet. 


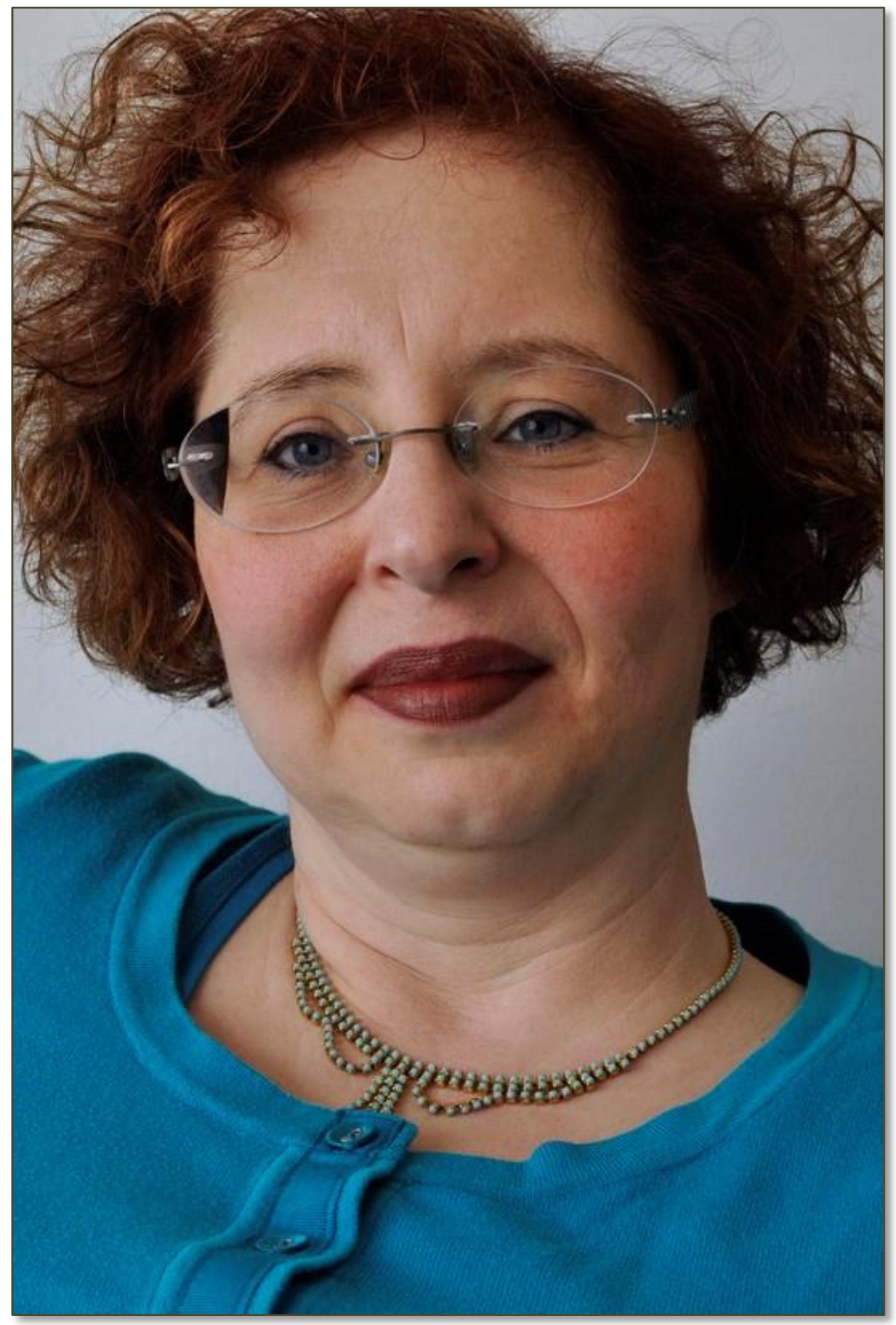

Mari Alföldy 
Met betrekking tot dit moment vind ik de vraag moeilijker te beantwoorden. Ik ben net met Oorlog en oorlog van Krasznahorkai bezig, maar ik heb de indruk dat er de laatste jaren minder uitgegeven wordt. Helaas heeft Hongarije de laatste jaren een beetje een slechte naam gekregen in het Westen, en ook het feit dat de Hongaarse overheid weinig doet om de grote namen van de Hongaarse literatuur te promoten omdat ze geen van allen vrienden van het regime zijn, speelt waarschijnlijk een rol.

Jij doet ook veel voor Hongaarse cultuur in Nederland. Jij organiseert culturele evenementen. Trekt dat veel publiek?

Veel zou ik het niet noemen maar genoeg om ermee door te gaan. In 2008 richtte ik (samen met anderen) de Hongaarse Salon Amsterdam op en sinds die tijd organiseren we maandelijks Hongaarse culturele evenementen voor Hongaren en iedereen die geïnteresseerd is in Hongaarse cultuur. In principe zijn dat om en om films en live evenementen, de laatste kunnen literaire programma's zijn, lezingen, concerten, kleinschalige theatervoorstellingen. Dit is een onafhankelijk podium, gerund door vrijwilligers, dat bestaat van entreegelden en donaties en mede mogelijk gemaakt wordt door het Goethe-Institut dat voor een vriendenprijs zijn prachtige ruimte beschikbaar stelt. De films zijn altijd ondertiteld (meestal in het Engels). Lezingen en dergelijke zijn in de meeste gevallen in het Hongaars, maar we doen ons best om de programma's zo veel mogelijk ook voor niet-Hongaarssprekenden toegankelijk te maken: soms is er muziek, soms zorgen wij voor simultaanvertolking of organiseren we tweetalige evenementen. We hadden een gesprek met de in Hongarije wonende Nederlandse schrijver Jaap Scholten met simultaanvertaling in het Hongaars of de schrijver György Spiró en filosofe Ágnes Heller met vertolking naar het Nederlands respectievelijk het Engels. In juni 2020 was ons eerste live evenement na twee Hongaarstalige online evenementen in coronatijd een wandeling door het centrum van Amsterdam, waarbij vier groepen een rondleiding kregen langs plekken met een Hongaarse connectie, twee in het Hongaars en twee in het Nederlands.

Er zijn traditioneel meerdere Hongaarse verenigingen in Nederland. Bv. Mikes Kelemen Kör, Hungária Club. Hoe populair en productief zijn deze verenigingen nog in de 21 ste eeuw? 
Ik moet eerlijk zeggen dat ik alleen de Hongaarse Salon regelmatig bezoek, maar voor zover ik weet bestaan de andere organisaties ook. De bezoekersaantallen van Mikes waren wel teruggelopen sinds de hoogtijdagen maar de laatste maanden zie ik weer interessante activiteiten door toedoen van een enthousiast nieuw bestuur, vooralsnog online vanwege de pandemie. Hungária Klub organiseert meer feesten en gezelligheidsbijeenkomsten, niet zozeer culturele evenementen.

Jij hebt zo ongeveer alles van Márai in het Nederlands vertaald. Gloed is tientallen keren herdrukt in de laatste twintig jaar. Hoe verklaar je dit enorme succes?

Dat is niet helemaal waar, ik heb alleen Gloed, De erfenis van Eszter en Land, land!... vertaald. Daarna hebben anderen (Margreeth Schopenhauer, Frans van Nes, Rogier van der Wal en Henry Kammer) een aantal andere boeken vertaald. Dat was een keuze van de uitgever om de boeken over meerdere vertalers te verdelen.

Wat de vraag zelf betreft, waarom Gloed zo populair was en is: als ik heel eerlijk ben, weet ik het ook niet echt. Zelf had ik het helemaal niet verwacht.

Ik kan natuurlijk wel een paar redenen bedenken: het is een goed verhaal, het leest makkelijk, met een duidelijke verhaallijn. Het is ook mooi geschreven, Márai is een goed stilist. Het is ook overzichtelijk, de schrijver houdt zich keurig aan de Aristoteliaanse eenheid van tijd, plaats en handeling. Anderzijds spreekt er een bepaalde romantiek uit ('Echte passie!' riep de uitgever toen ik de vertaalopdracht kwam bespreken). Er worden grote thema's behandeld: vriendschap, verraad, liefde en wraak. Ook ademt het een bepaalde nostalgie naar een verloren wereld. Voor de buitenlandse lezer helpt het dat er geen culturele achtergrondinformatie nodig is om het verhaal te kunnen volgen, het is slechts oppervlakkig geplaatst in tijd en ruimte, in tegenstelling tot een Krúdy of een Móricz, Ádám Nádasdy noemde het ooit „konvertibilis irodalom” (converteerbare literatuur).

Interessant genoeg wordt juist deze roman door Hongaarse literatuurkenners minder hoog aangeslagen, door sommigen wordt hij clichématig en banaal gevonden, een criticus heeft het over sententies en one-liners, Mihály Szegedy-Maszák noemt het gezocht en kunstmatig, maar roemt de zeer virtuoze omgang met de taal, László Rónay had het in zijn monografie uit 1998, N.B. het jaartal van de verschijning van de 
Italiaanse vertaling, over de meest virtuoze, maar minst geslaagde (of minst succesvolle? Het Hongaarse woord sikertelen laat beide vertalingen toe - het laatste is in ieder geval door de werkelijkheid achterhaald) onderneming van de schrijver.

Zelf hou ik het meest van zijn sfeerbeschrijvingen, zoals van de reis van de vader met Henrik en met zijn Franse vrouw door het Hongaarse landschap, of van het carnaval in Wenen, je ruikt en proeft wat hij beschrijft.

Misschien hoort ook bij de verklaring dat het een bepaalde romantiek heeft dat een vergeten schrijver wordt herontdekt, zeker gezien het tragische lot van Márai, die in 1989 na decennialange emigratie en publicatieverbod in eigen land ziek, oud en vergeten zelfmoord pleegde, nog geen jaar voor de val van de muur en zijn herontdekking in Hongarije, en enkele jaren voor zijn grote triomftocht over de hele wereld.

Kun je iets vertellen over het vertalerberoep? Hoe kies je een werk dat je gaat vertalen? Wat is de rol van de uitgever bij de keuze?

Voor vertalers Hongaars is er niet continu aanbod van werk. Als zelfstandige vertaalde ik niet alleen literatuur, maar tolkte ook en deed juridisch en ander vertaalwerk, zo kon ik beschikbaar blijven voor literaire vertalingen wanneer die zich aandienden. In de meeste gevallen word je gevraagd voor een opdracht, maar ik probeer ook zelf regelmatig uitgevers te benaderen met voorstellen voor Hongaarse boeken. Dat levert lang niet altijd resultaat op maar toch heb ik enkele keren een uitgever kunnen overhalen om een Hongaarse auteur uit te geven. Zo mocht ik Géza Ottlik, Pál Závada en Margit Kaffka vertalen, en ook László Krasznahorkai was één van de auteurs die ik jarenlang had geprobeerd ergens onder te brengen. En ik heb nog ideeën...

Wat vindt het Nederlandse publiek van Hongaarse literatuur? Wat is je persoonlijke ervaring?

Op een gegeven moment kende iedereen die wel eens een boek las de naam Márai en hadden heel veel mensen Gloed gelezen, dat was erg leuk om mee te maken. En als mensen horen dat ik me met Hongaarse literatuur bezighoud, komen ze nu, 20 jaar na dato, nog steeds met Konrád die ze gezien hebben in de programma's van Wim Kayzer. Krasznahorkai is 
geen schrijver voor de massa maar er zijn mensen die uitkijken naar de verschijning van zijn boeken in het Nederlands.

Hoe wordt Hongaarse cultuur gepromoot in Nederland? Zijn dat vooral privé-initiatieven, verenigingen of is er ook steun van de staat?

Er zijn af en toe initiatieven van de ambassade, maar echt systematisch gebeurt het niet. Het Balassi Instituut in Brussel zou officieel de hele Benelux moeten bedienen maar dat gebeurt nauwelijks, of ik kan beter zeggen: helemaal niet. Nog afgezien van het feit dat de cultuur steeds meer beïnvloed wordt door de politiek, dus staatssteun is ook niet per se gelukkig.

Wat voor literatuur is nu hip in Nederland? Waar werk jij nu aan?

Ik werk aan Oorlog en oorlog van Krasznahorkai, of je Krasznahorkai hip kunt noemen weet ik niet maar hij heeft wel een schare fans in Nederland. Over het algemeen lezen de mensen vooral Engelstalige literatuur, al dan niet in vertaling.

In de jaren negentig was György Konrád 'de Hongaarse auteur' in Nederland (vertaald vooral door Henry Kammer). Daarna kwamen Nádas en Esterházy en ook anderen. Welke Hongaarse auteurs zijn tegenwoordig bekend bij het Nederlandse publiek?

Over Konrád heb ik al gesproken. Nádas werd in de jaren '90 wel gelezen maar helaas is zijn magnum opus Parallelle geschiedenissen niet in het Nederlands vertaald, om maar niet te spreken van zijn lijvige memoires Oplichtende details: zulke dikke boeken durven uitgevers tegenwoordig niet aan. Het werk van Péter Esterházy, in 2016 overleden, sloeg in Nederland weinig aan, mogelijk door zijn focus op spelen met de taal. Van de recent verschenen auteurs is Krasznahorkai de bekendste, uiteraard bij een beperkt publiek. Ook András Forgách' De akte van mijn moeder (Hongaarse titel: Élö kötet nem marad), verschenen in vertaling van Rebekka Hermán Mostert, kreeg goede kritieken.

Hoe zie je de toekomst van vertaalde literatuur en speciaal Hongaarse literatuur in Nederland? 
Collega-vertalers die op een boekenmarkt stonden namens de Boekvertalers, de gemeenschap behorende bij de gelijknamige mailinglist, vertelden dat ze verbaasde mensen aan hun stand kregen die ervan overtuigd waren dat boeken tegenwoordig door de computer werden vertaald. Ik hoef hier niet uit te leggen dat het niet zo is, en ik denk ook niet dat dat in de nabije toekomst zal gebeuren. Of de mensen die nu jong zijn over 50 jaar nog boeken zullen lezen, hetzij op papier, hetzij digitaal, durf ik niet te zeggen, maar zolang het lezen blijft en het Engels niet definitief alles overneemt, zullen er vertalers Hongaars-Nederlands en Nederlands-Hongaars nodig zijn. 